\title{
Gender Issues in Children's Literature: An Analysis of Fairytales
}

\author{
Tahira Akbar* \\ Ra'ana Malik $^{* *}$ \\ Farooq-e-Azam $^{* * *}$
}

\begin{abstract}
This paper intends to explore the reasons of gender discrimination in different segments of Pakistani society at grass root level. This study is based on qualitative content analysis of children's literature from which the most popular corpse of ten English fairytales purposively. Activities of different characters along with their social were selected and economic status, behavioral traits, gendered messages and thematic roles were analyzed by using coding frame for manifest and stimulus clues for latent information. This content analysis research indicates that gender difference is an integral part of the fairy tales which shows female gender inferior to male. A detailed qualitative analysis of these selected fairytales cited that gender issues start from titles and prevail throughout the fairytales. Males had proper names but girls were known with their attributive names in the titles. The study suggests a need for drastic change behaviorally, psychologically and materially (in our children's literature and particularly in fairytales) to keep pace with the $21^{\text {st }}$ century, which demands us to be more creative, active and innovative with scientific approach instead of becoming an escapist.
\end{abstract}

Keywords: fairy tales, gender roles, gendered messages

\footnotetext{
* Ph.D Scholar, Department of Gender Studies, Punjab University, Lahore.

** Assistant Prof. Department of Gender Studies, Punjab University, Lahore. Email: raana.malik@yahoo.com

${ }^{* * *}$ Ph.D Scholar Department of Gender Studies, Punjab University, Lahore.
} 


\section{Introduction}

Books are always considered a great source to reflect societal values, attitudes, norms and culture with some purpose; therefore, gradually but consciously this material especially the children's literature works on an epic scale to shape and sculpture human personality (Salem, 2006). Awareness of gender recognition with its related and associated features is a phenomenon which starts in the early stages of life and gets powerfully influenced by the type of literature children are exposed to in later stages (Janice, 2011). It is the basic dimension through which children explore their place in society and try to understand the social world phenomena. The process of gender identity which has often been allied with the sex-role in the society is a foremost developmental mission which starts at the age of two or three years and becomes quite solidified within the ambit of growth and grooming when child turns six years old. The child's social interaction with society, parents, teachers, caregivers, oral and written literary material and toys, all play a very crucial and important role in explaining the gender image to a child (Abbot,2005). This aspect of socialization basically points out the bitter truth that when a child reaches first level of socialization, he or she simply somersaults from mother's lap into the lap of society as he/she has clearly and definitely adopted the type of role he/she is to play for their stereotypical survival in society (Grenby, 2008; Maccoby \& Jacklin, 1978).

Irrespective of their origin, most of the famous stories and fairytales of all cultures have been translated in many languages of the world by various writers with some changes to keep a pace with time and prevailing circumstances (Lewis, 2011). The usual themes of children's books are a combination of fun and thrill, mind's eye and wonder, fancy and reality, excitement and venture, dream and desire (Frater, 2009). The charismatic presentation of the characters creates a dreamy environment which deeply impact children. These characteristics have made these fairytales a literature beyond the cultural boundaries and limitations, a universal phenomenon. These fairy tales are considered a very popular form of literature for children (Kready, 1961). As these stories were passed down through generations, orally and written, the message conveyed retains meanings regardless of time and place (Sapir,1954). These are fantastic and imaginative stories. Children are fond of such stories for multiple reasons and it is supposed that imaginativeness is an integral part of children's literature. Consciously, but gradually this material works on an epic scale to shape and sculpture human personality 
(Lewis, 2011). The audio visual aspect of these fairytales enhances the impact of this literature on reader and listener. However, children's literature of its earlier stage presents no optimistic view rather we are left in doldrums with despair, confusion and low morale as it is pregnant with prejudice regarding femininity and masculinity. A very strong, important and front line masculine figure prevails mainly in the stories we read to children with very weak, compliant, immature and unreceptive roles defined for feminine characters (Fox, 1993).

This study stumbled upon this above mentioned statements after analyzing some famous fairytales through their content analysis. The selection rationale was a great source of energy to complete this thought provoking work. Instead of taking a stereotype image of genders by following the beaten tracks, the researchers tried to open up new vistas positively. This deviation from these closed minded interpretations to a panoramic understanding regarding both genders would help to move forward progressively (Pusavat, 2007; MaCabe, Fairchild \& Tope, 2011). However, this requires a perspicacious understanding of available literature along with the social circumstances in which some particular reading material was produced. If this material continues and persists then it would indicate that gender patriarchal behaviors seems untouched with the advancement of knowledge and women's agency in almost every human field. Under the garb of children's literature, the rigid stereotypical thoughts are still being inculcated into the soft minds of children. Thus, there is need to ponder over this critical issue that either this children's literature keeps a pace with the current social realities or not.

\section{Research Questions}

i. How gendered identities are being constructed among children through popular children's literature in a larger social world?

ii. What types of character roles are portrayed in children's fairytales?

iii. What types of gendered messages are being transmitted in generations by fairytales?

iv. How is the positioning of genders located through linguistic capital used in children's literature?

v. How does the socio-economic status of various characters affect the lives of others in fairytales?

\section{Method}

The literature which is being read, listened and enjoyed in some segments of Pakistani culture, particularly English medium class as bed 
time stories by the children of 3 to 8 years old was the population for this study. This included ballads, fables, folktales, folklores, lulls, fairytales etc. in English language. Ten fairytales from this population were selected purposefully as this genre of literature is charged with fantasy, imagination and later on with day dreaming. The popular fairytales selected by the researchers included Aladdin and his magic lamp, Rapunzel, Jack and the Beanstalk, Little Red Riding Hood, Snow White and the Seven, Dwarves, Cinderella, Beauty and the Beast, Sleeping Beauty, Ali Baba and Forty Thieves, and Rumpelstiltskin. The researcher also interviewed (non-formal) 10 mothers buying fairytales for their children by visiting different book stores. The talk with mothers further confirmed the popularity of the selected fairytales for the study. The researcher used content analysis of gendered messages in the fairy tales by using a coding frame specially designed for this purpose. Tales were read and their findings were recorded by giving conscious attention to characters, role assigned to various characters and subject that were orthodox and formulaic. Coding frame is based on traditional gender usually stereotypes (Nair, 2008; Walker, 2007). A Coding frame is developed for manifest content analysis and latent content analysis is done through stimulus clues.

\section{Results}

\section{Names and Titles}

The first thing which gets the attention of the reader is the title of any story. There were three out of seven stories which had male names as the titles of fairytales. The titles of fairy tales showed an interesting but strange background with such a deep consistency which is worth to be mentioned. Female characters were not given worth enough to give them proper names even such as sleeping beauty, Beauty and the Beast, Little Red Riding Hood etc. On the contrary, the male characters had proper names (Aladdin and the Magic Lamp, Jack and the Beanstalk, Ali Baba and Forty Thieves) due to which we could observe an obvious discrimination between male and female characters' presentation.

\section{Gender Placement and Location}

All the heroines in the tales were always in the ambit of socially defined female space which means either they were inactive and 
abandoned in their house, room or tower or if active then doing home chore activities or needle work. For example, Sleeping Beauty was shown lying inactive in her bed, Rapunzel in a tower and Snow White, Cinderella and Beauty performing house hold activities in the house. "The poor child was sent to live in the kitchen where she had to do all the rough and dirty work", (Cinderella). When Snow White requested the dwarves to let her stay in their house, they unanimously allowed her with the condition related to perform inner house hold activities. "The dwarves spoke with each other for a while and then said, "if you will keep house for us, and cook, make beds, wash, sew, and knit, and keep everything clean and orderly, then you can stay with us, and you shall have everything that you want"(Snow White \& Seven Dwarves). These explicit examples from the stories make it very clear that all the female characters fall almost in the same category of home chores activities in a way or other. This female space includes all females irrespective of their social or economic status. On the contrary, no prince or even an ordinary man was shown inactive or lying on the bed waiting for the princess for his rescue or survival. There is no question of being shutting them in the four walls. If a prince was shown, then he was doing no work, only in an adventurous mood whilst ordinary man could be seen doing some work. As in "Sleeping Beauty", the prince was outside the castle, only to find out something in solitude which he could not find in the company of other people. In "Rapunzel", the prince was riding through the wood when accidently he heard Rapunzel's singing. There was no reference of his work, job or any specific activity. In "Cinderella", the prince arranged a party to choose his bride. His enjoyments, search for the bride, interaction with Cinderella, his deep love for her, his search for her beloved, his success in search, all was mentioned except his job or any reference of his work. In Snow White and the Seven Dwarves, "men of abnormal physical growth "owned a house" and in the house, though things were tiny, but were neat and clean. Along with these household activities they all went out to earn their livelihood. The dwarves were seven in number and "mined for gold in the mountains".

This social positioning of female and male characters is not due to their biological predisposition but due to socially and culturally set patterns. And these socialization patterns are gender specific.

\section{Importance and Impact of Social and Economic Status}

Economic and social status shows the ability of the characters to hold power and authority which establishes one's position in society. The 
social and economic status of male is always shown better in position and this is made understood with the word "prince" due to which girls readily accepted their hand. As prince were always in the position of affluence, therefore, they took girls along with them and ensured a wonderful, carefree and happy future.

If we look at the economic and social status of the characters in the fairytales, it could be observed that "Sleeping Beauty" and 'Snow White' were the born princess and to get married with prince was their right, but in 'Rumpelstiltskin, a miller's daughter, raised to the status of a queen conditionally, not due to her beauty but as result of the completion of the task assigned to her. Here no love or physical attraction but the greed of the king made a poor girl his queen. As it is mentioned in the story that when the miller brought the girl to the king, the king along with the girl went to the room where he had kept straw to be turned into gold. "Turning to the girl, the king said, if youdo not spin the entire heap of straw into gold by morning, your head shall be cut off. But if you do spin the gold, I will marry you and make you my queen". The king considered it the best prize for an ordinary girl to be his queen without taking or considering her wish. Rapunzel attracted the prince because she got lovely voice and sang wonderfully. She was captivated in a tower by a witch who had snatched her from her parents since her childhood and after a year or two, it came to pass that the prince rode through the forest and went by the tower. He heard a song which was so lovely that he stood still and listened. This was Rapunzel who in her loneliness passed her time singing and then her social status was raised when "he asked her if you will take me as your husband". She saw that the prince was kind and handsome. She said yes, and laid her hand in his hand. He led her to his kingdom where he was joyfully received, and they lived for a long time afterwards, happy and contented.

Aladdin in "Aladdin and the Magic Lamp" was an impoverished boy who lived in utter poverty, found the magic lamp and became rich. He got the hand of the daughter of a king when he became rich. He felt in love with king's daughter because of her beauty but the king did not agreed. The king gave consent only Aladdin gave him costly gifts. "Looking at the magnanimous gifts, the king readied to give his daughter in marriage. Aladdin wished for a palace and the same was granted for the newly married couple".

In this context, we could see that multiple reasons are involved in raising the social and economic status of both male and female characters. No doubt in most of the stories, the physical beauty of female characters remained a great source of their elevation in the social ladder. 
But it is also worth mentioning that the socio-economic status of almost all the females was raised due to the male characters. The socioeconomic status of male was always shown better than the female characters. In fact, any status designated to female was by male character; otherwise she occupied no place herself. When a girl was owned and accepted by a male only then her status was raised and this thing became a source of satisfaction and happiness for the girl, that's why they were always willing to go along with them. This impression is spread through fairytales as a socially accepted norm irrespective of any particular culture or society. A collective impact is served to create a consciousness about the upper hand of male gender in social formulations.

\section{Gendered Messages and Gendered Thematic Roles}

All heroes, in the selected fairy tales, were shown brave, analytical, adventurous, rational, intelligent, planners, aggressive and active, except Beast (Beauty \& the Beast) who was not aggressive or adventurous but active and vigilant because he depended on Beauty for his disenchantment. Princes were usually in the position of affluence and were the paragon of felicity who with their bravado impressed the readers and listeners of the fairy tales. The only negative male character was Beast but he also had the qualities of all good and great virtues. No heroine, except Beauty, is assertive, strong, analytical and intelligent. The Heroines of the fairy tales were contented and submissive. They were weak and could not save themselves from the opposing forces. Only one heroine Beauty in "Beauty and the Beast" was shown adventurous, explorative, daring, intellectual, wise, brave, contented and intelligent. She was a brave but also very emotional girl. She was assertive but ready to sacrifice for others. Beauty, Little Red Riding Hood, Snow-White and Cinderella remained active in the fairy tales whereas Rapunzel and heroine of "Rumpelstiltskin" remained inactive and most of the time weeping and sobbing.

Secondary or minor characters also show obvious gender differences based on their roles. The male secondary characters were also shown kind, helping, cooperative and good natured. On the contrary, the female minor characters were presented as unkind, unsympathetic, harsh, mean, irrational and aggressive. All witches were females who were devoid of human blood of kindness. Witches and step mothers represented a very gruesome picture of female. They were shown either as harridan or as termagant. They all lacked vision and are temerarious. Thus, the 
stereotypical issues and attributes, transmitted through gendered messages are made deep rooted, permanent and universal. The consistent repetition shows that this thing is not unintentional but deliberate and socially embedded.

\section{Discussion}

The research indicates that the tags of boy and girl at the time of birth (biological reality), later on decides about the potential gender roles of both gender in a society. In spite of changed cultural and social circumstances, polarization of interests, activities and gender differences, which usually prevail in most areas and strata of our lives, this should not be taken as natural but socially, historically, and in much broader term, culturally determined. Children's literature often models thinking patterns; therefore ideas must be filtered and manipulated to encourage the children to dream big with this conviction that they can be successful in any field when they grow up. Our identities are created within the relations that we share with others and not wholly as an abstract within ourselves (Oskamp \& Others, 1996).

The proposition that a man can do what a woman cannot do, can be based on their biological positions, but not on their mental, spiritual or intellectual ones. As Beauvoir (1952) also argues that, "one is not born a woman, but becomes one". Not the natural but the cultural frame work and gender shackles are making cultural norms function as law. Why do we always interpret fairy tales traditionally? In fact, it is nothing else but our stereotypical interpretations which make us gender specific. Though we know that one stereotypical expectation depends on another stereotypical expectation and this vicious cycle goes on. This point of view is also supported by Taylor (2003), who admits that children are initiated into racial discrimination, community, class and gender roles at such a young age that they themselves do not realize and remain unable to evade these biases with which they are fed for a long time along with their growth and grooming process.

If we look at the illustration of the page covers of the fairy tales, it can be easily observed that female is not always underrepresented but is physically portrayed as a charming, attractive and delicate creature to be loved and adored. She is never shown with any such thing which can give any reference to her intellectual status. On the contrary, male figures are always represented with something which shows them dominating, active and alert. The content analysis undertaken shows a very clear and 
obvious gender disparity in male and female characters' portrayal in fairy tales.

Here a question rises, does fairytales provides children such imaginations which are a shelter and an escape from the bitter realities of the world for the time being? The researchers believe this is not the case. If the purpose of the fairytales is only to create an atmosphere of escape from the bitter realities of the real world and to put children under the umbrella of fantasy, then why to drag children in the unrealistic environment of the remote past only? These traditional fairy tales and the characters of these fairy tales contribute little in the grooming of the children. These tales are unable to pull children on the progressive track and instead of modernity, keep their minds and fertile thoughts in Stone Age. The question is then, why don't we change and present children the incredible and fantastic aspects of the future? Why cannot we sharpen the imaginative powers of the children? An escape would be there but a creative, modern, innovative, technical, latest and scientific one. This concept would be a lubricant to push the children a step ahead. The children should not be taken in by the specious reasoning of the fairy tales. We should try to develop their minds proactively. Importantly, instead of creating a terror, fright and phobia in the minds of young readers by introducing the fairy tales creatures, such creatures can be introduced which are human friendly, moderate and attractive for the better future prospects of children. Moral and mental corruption through gender difference is an integral part of these typical fairy tales by showing female gender inferior to male gender in all respects.

Furthermore, a contradiction which looks strange in the fairy tales is that the male characters were presented very kind hearted and they immediately became ready to save the female characters; as huntsman did with Snow White and Little Red Riding Hood was saved by an ordinary character. On the other hand, female characters especially mothers were shown termagant, intractable, carnal, weak, fragile and hard hearted. Walker (2007) in her study also concluded that in the fairytales, females were presented as fragile creature who always need a male's assistance; emphasizing the idea that a male is to protect women and women's pure intention is to look after and think about their family. Hence, there is a linear relationship between the perception of children and the impact of these fairy tales on them. This point was also mentioned by Pirofski (2012) that young ones automatically get prepared and construct messages about their role in society and cultural norms performed by them. 


\section{Recommendations}

The future authors should develop a panoramic view to replace stereotyped vocabulary with the ornaments of gender free words to decorate the children's stories. Gender stereotype frame of coding should be replaced with gender free occupation with functional description of clothing positively. Parents should adopt non-traditional interpretations of the text of fairytales. Further, Educationists can make fairy tales part of the text as a positive and an effective tool to educate people that intellect is superior to physical beauty; good virtues and intrinsic worth are not the discretion of any one gender. 


\section{References}

Abbott, T. (2005). Social and personality development. London: Routledge.

Beauvoir, Simone de. (1989). The second sex. New York: Vintage Books.

Grenby, M. O. (2008). Children's literature. Edinburgh: University Press.

Fox, M. (1993). Men who weep, boys who dance: The gender agenda between the lines in children's literature. Language Arts, 70(2), 8488 .

Frater, J. (2009). Art and literature. Retrieved from www.listverse.com on $23^{\text {rd }}$ Jun 2018.

Janice Mccabe, E. F. (2011). Gender in twentieth century children's books. Gender and Society, 25(2) 197-226.

Kready, L. F. (1961). A study of fairy tales. E-book Source: http://www.sacred-texts.com

Lewis, C. S. (2011). The Importance of teaching literature to children. Retrieved from http://www.studymode.com/essays/The-ImportanceOf-Teaching-Literature-To-605570.htmlon 23rd June 2018.

Maccoby, E. E., \& Jacklin, C. N. (1978). The psychology of sex differences (Vol. 2). Stanford University Press.

McCabe, J., Fairchild, E., Grauerholz, L., Pescosolido, B. A., \& Tope, D. (2011). Gender in twentieth-century children's books: Patterns of disparity in titles and central characters. Gender \& Society, 25(2), 197-226.

Nair, R. (2008). A content analysis of gender representation in Malaysian children's literature. Social and Management Research Journal, 5(2), 49-60.

Oskamp, S., Kaufman, K., \& Wolterbeek, L. A. (1996). Gender role portrayals in preschool picture books. Journal of social behavior and personality, 11(5), 27-39. 
Pusavat, G.S. (2007). Gender perception: Differences for relationships portrayed on television. (Unpublished Thesis). Cornell University, New York, US.

Pirofski, K. I. (2012.). Race, Gender, and Disability in Today's Children's Literature. Retrieved from http://www.edchange.org/ multicultural/papers/literature2.html $7^{\text {th }}$, May 2018

Salem, A. L. (2006). Children's literature studies: Case studies and discussion. New York: Greenwood Publishing Group.

Sapir, W. L. (1954). The relation of habitual thought and behavior to language" In Carrol (ed.) Social and personality development. London: Belmont, pp.92-105.

Taylor, F. (2003). Content analysis and gender stereotypes in children's books. Teaching Sociology, 31, No. 3, 300-31

Walker H. E. (2007). A content analysis on the meaning of disenchantment in fairy tales. (Unpublished Thesis). USA: University of North Carolina.

\section{Citation of this Article:}

Akbar, T., Malik, R., \& Farooq-e-Azam. (2018). Gender issues in children's literature: An analysis of fairytales. Pakistan Journal of Education, 35(1), 59-70.

Received on: July

12,2017

Revised on: January

Accepted on: March
15,2018

22,2018 